\title{
PENGARUH MEREK TERHADAP PERILAKU KONSUMEN ATAS PRODUK HANDPHONE NOKIA DI KALANGAN MAHASISWA FISIP UNIVERSITAS TULANG BAWANG BANDAR LAMPUNG
}

\author{
Oleh: \\ Sophan Syaiful ${ }^{1}$ \\ Rusli $^{2}$ \\ Program Studi Manajemen Universitas Mitra Indonesia Lampung ${ }^{1}$ \\ Program Studi Administrsi Bisnis, Universitas Tulang Bawang Lampung ${ }^{2}$ \\ e-Mail: rachmatandfamily@gmail.com
}

\begin{abstract}
ABSTRAK
Seiring dengan berkembangnya teknologi, masyarakat Indonesia khususnya yang hidup di wilayah perkotaan mulai mengalami gaya hidup . Bagi mereka Handphone (HP) atau ponsel tidak hanya digunakan sebagai alat telpon atau sms saja, tetapi mereka juga sudah memperhatikan fitur-fitur lainnya yang mulai terdapat pada semua jenis dan tipe handphone yang beredar di pasaran. Selain itu, merek handpone pun sudah menjadi pilihan gaya hidup mereka, salah satunya adalah handphone merek nokia yang sudah di kenal di pasaran oleh masyarakat Indonesia pada umumnya.Adapun teknik sampling yang digunakan adalah random sampling, yaitu pengambilan sampel secara acak, dan sampel yang dipergunakan sebesar 50\% dari populasi, adapun jumlah sampel penelitian yaitu 133 orang.Kesimpulan dalam pelaksanaan penelitin ini sebagai berikut: faktor social dan budaya, seperti saran teman-teman terdekat, ataupun keluarga yang ada menjadi acuan atau informasi tersendiri bagi prilaku konsumen dalam pembelian produk handphonenokia selain masalah harga juga menjadi acuan yang penting.Dalam dimensi merek sebuah produk, factor ketahanan dan kehandalan serta factor karakteristik produk seperti corak, penampilan, dan daya tarik produk, menjadi faktor dominan bagi konsumen mengenair kualitas produk handphone Nokia.Berdasarkan hasil perhitungan, maka di dapat untuk : rhitung adalah 0,404. Apabila di konsultasikan dengan rtabel untuk paraf signifikan 5\% adalah 0,176. Ternyata $r$ hitung lebih besar dari pada $r$ table atau : rhitung $(0,404)>$ rtabel $(0,176)$ pada taraf signifikan 5\% dengan demikian merek mempunyai pengaruh yang positif terhadap prilaku konsumen atas produk handphone Nokia di kalangan Mahasiswa FISIP UTB LAMPUNG.
\end{abstract}

Kata kunci: pengaruh; merek; perilaku; konsumen; produk 


\section{PENDAHULUAN}

\subsection{Latar Belakang Masalah}

Dalam abad millennium seperti sekarang perusahan dituntut bersaing secara kompetitif dalam hal menciptakan dan mempertahankan konsumen yang loyal (pelanggan), dan salah satunya adalah melalui "perang" antar merek. Perusahaan semakin menyadari merek menjadi faktor penting dalam persaingan dan menjadi assetperusahan yang bernilai.

Iklim usaha yang semakin menantang, seperti dalam dunia industrytelephoneselular sekarang membuat manjemen perusahaan, baik yang baru maupun yang lama dapat menjawab tantangan pasar dan memanfaatkan peluang pasar dalam struktur persaingan dimasa kini maupun dimasa mendatang. Dalam keadaan ini pihak perusahaan di tantang untuk lebih berperan aktif dalam mendistribusikan dan memperkenalkan produknya agar laku terjual atau setidaknya mempertahankan bangsa pasarnya.

Hal ini berlaku pula di dalam persaiganindustrytelephone seluler atau biasa akrab di sapa dengan sebutan ponsel. Inovasi, kualitas, atribut, citra merek, dan tingkat harga produk, menjadi hal-hal yang harus di perhatikan oleh produsen ponsel, agar tidak di kalahkan ole pesaingnya. Kemajuan tekhnologi dalam hal efisiensi biaya dan inovasi sangat mendukung pertumbuhan bisnis selular. Selain itu, adanya perubahan seperti kemajuan di bidang pendidikan, peningkatan pendapatan masyarakat dan semakin majunya teknologi informasi dan komunikasi turut mendorong peningkatan penggunaan telepon selular.

Seiring dengan berkembangnya tekhnologi, masyarakat Indonesia khususnya yang hidup di wilayah perkotaan mulai mengalami perubahan gaya hidup. Bagi mereka, handphone atau ponsel tidak hanya digunakan sebagai alat telepon atau sms saja, tetapi mereka juga sudah memperhatikan fitufiturnya yang mulai terdapat pada semua jenis dan tipe hamdphone yang beredar di pasaran.

Nokia sejak dahulu telah menjadi penguasa pasar ponsel dunia, akan tetapi dunia ponsel bukanlah milik nokia sendiri. Makin banyak merek-merek pesaing bermunculan yang siap menggeser bangsa pasar Nokia.buktinya,nokia mencatat hasil kuartalan terburuk dalam satu dekade ini.

\subsection{Identifikasi Masalah dan Masalah pokok}

Identifikasi masalah penelitian ini adalah :

a. Bagaimana konsumen mengetahui kualitas produk handphone

b. Apa yang menjadi factor utama konsumen dalam melihat kualitas suatu produk handphone

Berdasarkan identifikasi masalah tesebut di atas maka masalah pokok dalam penelitian ini adalah apakah merek berpengaruh terhadap prilaku konsumen.

\subsection{Tujuan dan Manfaat Penelitian}

Berdasarkan perumusan masalah di atas maka yang menjadi tujuan dalam penelitian ini adalah :

a. Untuk mengetahui bagaimana konsumen mengetahui kualitas produk handphone.

b. Untuk mengetahui apa yang menjadi factor utama konsumen dalam melihat kualitas suatu produk handphone penelitian ini diharapkan dapat memberikan manfaat atas produk sebagai berikut : 
1. Signifikan Akademi

Penulisan ini diharapkan dapat memberi konstribusi bagi ilmu pengetahuan mengenai pengaruh merek terhadap prilaku konsumen atas produk Handphone Nokia.

2. Signifikan praktis

Memberikan informasi tambahan bagi produsen dan pemasaran untuk dapat membangun presepsi produk handphone di dalam pasar yang sangat bersaing berdasarkan kualitas sehingga produk atau merek dapat memperoleh perhatian konsumen dalam bangsa pasar.

\subsection{Kerangka Pemikiran}

Merek merupakan hal yang sangat penting bagi produsen maupun konsumen. Merek hanya simbol yang di pakai untuk mengidentifikasi produk atau perusahaan. Saat ini peranan atau fungsi dari suatu merek (brand) bukannya hanya sebagai pembeda dari produk yang dihasilkan oleh produsen yang satu dengan produsen yang lainnya, namun merek merupakan penentu dalam menghasilkan suatu competitifeadventages.

Konsumen cenderung menilai kualitas suatu produk berdasar factor-faktor yang mereka asosiasikan dengan produk tersebut faktor tersebut dapat bersifat intrinsik yaitu katakteristik

produk seperti ukuran, warna, rasa atau aroma dan faktor ektrinsik seperti harga, citra took, citra merek, dan pesan promosi.

Menurut Kolter dan Armstrong, 2001: 197212 , ada 4 faktor yang mempengaruhi prilaku konsumen.

a. Faktor Budaya
Faktor budaya mempunyai pengaruh yang luas dan mendalam terhadap prilaku, mencakup budaya(kultur,subudaya,dan kelas sosial). Budaya adalah susunan nilainilai dasar, presepsi, kenginan, dan prilaku yang di pelajari anggota suatu masyarakat dari keluarga dan institusi penting lainnya.

b. Faktor Sosial

Selain faktor budaya, prilaku konsumen juga di pengaruhi oleh faktor-faktor social seperti kelompok acuhan, keluarga, serta peran dan status. Kelompok acuhan adalah kelompok yang memiliki pengaruh langsung atau tidak langsung terhadap prilaku seseorang.

c. Faktor Pribadi

Keputusan seorang pembeli juga dipengaruhi oleh karakteristik pribadi seperti umur pembeli dan tahap siklus hidup, pekerjaan, keadaan ekonomi, gaya hidup, dan kepribadian

d. Faktor Psikologis

Faktor psikologis yang mempengaruhi pilihan pembelian yaitu motivasi, persepsi, pengetahuan serta keyakinan dan sikap. Motivasi adalah kebutuhan yang cukup mendorong seseorang untuk bertindak, sedangkan persepsi adalah proses bagaimana seseorang memilih, mengatur,dan menginterpretasikan masukan informasi untuk menciptakan gambaran berarti.

\subsection{Hipotesis}

Hipotesis adalah sebuah taksiran atau referensi yang dirumuskan serta diterima untuk sementara yang dapat menerangkan faktafakta yang diamati ataupun kondisi-kondisi 
yang diamati, dan digunakan sebagai petunjuk untuk langkah penelitian selanjutnya.

\subsection{Operasional Variabel}

\section{Variabel Bebas (x)}

Adalah suatu variable yang mempengaruhi lainnya, dalam hal ini variable $\mathrm{x}$ adalah merek handphone Nokia.

a. Definisi Konsepsional variable (x) Menurut ( Kolter\&Amstrong, 2001:360), merek adalah simbol yang dipakai untuk meidentifikasikan produk atau perusahaan dan merupakan salah satu hal yang sangat penting dalam melakukan keputusan pembelian, merek merupakan suatu nilai tambah (value) bagi suatu produk.

b. Definisi Oprasional (x)

Merek adalah simbol yang dipakai untuk mengidentifikasikan produk handphone Nokia dan merupakan salah satu hal yang sangat penting dalam melakukan keputusan pembelian, dan merupakan suatu nilai tambah (value) bagi suatu produk Handphone.

c. Indikator Variabel (x)
1. Kinerja
2. Pelayanan
3. Ketahanan
4. Daya beli masyarakat

2. Variabel terkait (y)

Adalah suatu variable yang dipengaruhi variable lainnya, dalam hal ini variable y adalah perilaku konsumen.

a. Definisi Konsepsional variable (y)
Organisasi dalam mendapatkan, menggunakan suatu produk, pelayanan dan sumber-sumber lainnya

b. Definisi Operasionalvariabel y

Perilaku konsumen adalah tindakantindakan, proses-proses dan berhubungan sosial yang dilakukan konsumen dalam mendapatkan menggunskan suatu produk handphone sebagai suatu akibat dari pengalamannya dengan produk handphone, pelayanan dan sumber sumber lainnya.

c. Indikator Variabel y

1. Budaya

2. Sosial

3. Pribadi

4. Psikologis

\section{TINJAUAN PUSTAKA}

\subsection{Tentang Merek}

Merek adalah nama terminology, tanda, simbol, atau desain atau kombinasi diantaranya, yang ditunjuk untuk mengidentifikasikan barang atau jasa dari suatu penjual atau kelompok penjual dan untuk membedakannya dari pesaing. Beberapa bagian merek antara lain dalah nama merek, tanda merek, merek dagang, dan copyright. Nama merek adalah bagian dari merek yang dapat disebutkan atau dijeda. Tanda merek yang diberikan untuk melindungi secara hukum yaitu melindungi penjual untuk menggunakan hak eksekutif untuk menggunakan nama merek dan tanda merek. Copyright adalah hukum eksekutif yang diberikan untuk menggandangkan, mempublikasikan, dan menjual segala sesuatu yang berbentuk buku, music atau karya artistk. 
Merek yang kuat ditandai dengan dikenalnya suatu merek dalam masyarakat, asosiasi merek yang tinggi pada suatu produk, persepsi positif dari pasar dan kestian konsumen terhadap merek yang tinggi.

Dengan adanya merek yang membuat produk yang satu beda dengan yang lain diharapkan akan memudahkan konsumen dalam menentukan produk yang akan dikonsumsinya berdasarkan berbagai pertimbangan serta menimbulakankesetian terhadap suatu merek (brandloyality).

Pemilihan merek bisa di lakukan dengan memilih nama merek yang mudah di ingat oleh konsumen, sebab dengan itu, konsumen tidak akan kesulitan untuk mencari produk tersebut. Suatu produk juga bisa memilih merek yang unik, dengan naman merek yang unik, konsumen akan merasa penasaran untuk mengetahui tentang produk tersebut dan mungkin akan mencarinya produk apa yang ada di balik nama merek yang unik tersebut.

\subsection{Produk}

\section{A. Pengertian Produk}

Produk adalah segela sesuatu yang dapat memenuhi dan memuaskan kebutuhan dan keinginan manusia, baik yang dapat diraba atau nyata maupun tidak dapat diraba atau jasa atau layanan.

Wujud produk adalah ciri-ciri atau sifat-sifat produk yang dilihat oleh konsumen dan diperlukan untuk memenuhi kebutuhan dan keinginan. Penekanan wujud fisik produk adalah termasuk fungsi dari produk tersebut disamping desain, warna, ukuran, dan pengepakannya,. Dari wujud produk fisik inilah konsumen atau pembeli dapat membedakan antara suatu produk dengan produk lainnya.

Dengan adanya atribut yang melekat pada suatu produk yang digunakan konsumen untuk menilai dan mengukur kesesuaian karakteristik produk dengan kebutuhan dan keinginan. Bagi perusahaan dengan mengetahui atribut-atribut apa saja yang bisa mempengaruhi keputusan pembeli maka dapat ditentukan strategi untuk mengembangkan dan menyempurnakan produk agar lebih memuaskan konsumen.

Suatu produk harus memiliki atribut yang mendukungnya, contohnya adalah harga yang berfungsi sebagai harga beli yang berlaku bagi konsumen. Berikut ini adalah atribut yang harus ada dalam suatu produk, yaitu :

a. Harga

Harga adalah jumlah uang yang ditagihkan untuk suatu produk atau jasa, jumlah ini yang dipertukarkan konsumen untuk manfaat yang dimiliki dengan menggunakan produk atau jasa.

b. Merek

Merek adalah semua nama, istilah, tanda, simbol, desain atau kombinasi dari semua yang di maksudkan untuk mengidentifikasi produk dari salah satu penjual untuk membedakannya dengan produk pesaing.

\section{c. Kemasan}

Kemasan adalah pembukus luar produk yang berfungsi untuk melindungi produk, memudahkan konsumen dalam memakainya, menaikan citra produk atau bahkan sekaligus dijadikan alat promosi ketika produk yang di lemparkan kepasaran. 
d. Kualitas

Kualitas merupakan salah satu atribut produk yang paling penting dimata konsumen. Konsumen akan berusaha mencari produk yang paling berkualitas tinggi, karena menyangkut kepuasan konsumen.

e. Ukuran

Ukuran suatu produk mempunyai hubungan yang erat dengan kebiasaan pembeli jumlah kebutuhan konsumen. Ini berarti kebutuhan antara konsumen yang ssatu dengan konsumen yang lainnya berbeda-beda, sehingga perlu menyediakan produk dengan berbagai macam ukura.

\section{B. Atribut Produk}

1. Merek (branding)

Merek (brand) adalah nama, istilah, tanda, atau rancangan, atau kombinasi dari semua ini yang dimaksudkan untuk mengidentifikasi produk atau jasa dari satu atau kelompok penjual dan membedakannya dari produk pesaing.

\section{Pengemasan (packing)}

Pengemasan (packing) adalah kegiatan merancang dan membuat wadah atau pembungkus suatu produk. Pengemasan melibatkan merancang dan membuat wadah atau pembungkus suatu produk.

3. Kualitas produk (Product Quality)

Kualitas produk (Product Quality) adalah kemampuan suatu produk untuk melaksanakan fungsinya meliputi, daya tahan keandalan, ketepatan kemudahan operasi, dan perbaikan serta atribut bernilai lainnya.

\section{Tingkatan Produk}

1. Produk inti (core product)

Produk inti terdiri dari manfaat inti untuk pemecahan masalah yang dicari konsumen ketika mereka membeliproduk atau jasa

2. Produk actual (actual product)

Seorang perencana produk harus menciptakan produk tern (actual product) disekitar produk inti. Karakteristik dari produk tern diantaranya, tingkat kualitas, nama, merek, keman yang dikombinasikan dengan cermat untuk mrnyampaikan manfaat inti.

3. Produk tambahan

Produk tambahan harus di wujudkan dengan menawarkan jasa pelayanan tambahan untuk memuaskan konsumen, misalnya dengan menanggapi dengan baik claim dari kaonsumen dan melayani konsumen lewat telepon jika knsumen mempunyai masalah atau pertanyaan

\section{Klasifikasi Produk}

Produk dapat diklasifikasikan kedalam dua kelompok utama yaitu barang dan jasa. Ditinjau dari aspek daya tahannya terdapat dua macam barang, yaitu: 
1. Barang tidak tahan lama (nondurable goods)

Barang tidak tahan lama adalah barang berwujud yang biasanya habis dikonsumsi dalam satu atau beberapa kali pemakaian. Contohnya adalah sabun, minuman dan makanan ringan.

2. Barang tidak tahan lama (durable goods)

Barang tahan lama merupakan barang berwujud yang biasanya bisa bertahan lama dengan banyak pemakaian ( umur ekonomisnya untuk pemakaian normal adalah satu tahun atau lebih). Contohnya mobil, lemari es, dan TV.

Produk dapat dibedakan menjadi barang konsumen (costumer'sgood ) dan barang industry (industrial'sgoods). Barang konsumen adalah barang yang dikonsumsi untuk kepentingan konsumen dapat diklasifikasikan menjadi empat jenis yaitu:

a. Covinience goods

Covinience goods merupakan barang yang $\mathrm{p}$ [ada umumnya memiliki frekuensi pembelian tinggi (sering beli), dibutuhkan dalam waktu segera, dan hanya memerlukan usaha yang minimum (sangat kecil) dalam perbandingan dan pembeliannya.

b. Shopping goods

Shopping goods adalah barang-barang dalam proses pemilihan dan pembeliannya dibandingkan oleh konsumen diantara berbagai altrnatif yang tersedia c. Specially good spesially goods

Adalah barang-barang yang memiliki karakteristik dan identifikasi merek yang unik dimana sekelompok konsumen bersedia melakukan usaha khusus untuk membewlinya.

d. Unsought goods

Unsought goods merupakan barangbarang yang diketahui konsumen atau kalapun sudah diketahui tetapi pada umumnya belum terfiirkan untuk membelinya.

\subsection{Perilaku Konsumen}

Berdasarkan beberapa pendapat tersebut dapat disimpulkan bahwa perilaku konsumen adalah semua kegiatan, tindakan atau proses psikologis yang mendorong tindakan tersebut pada saat sebelum membeli, ketika membeli, menggunakan produk dan jasa setelah melakukan hal-hal tersebut.

Ada dua elemen penting dari arti perilaku konsumen yaitu proses pengambilan keputusan dan kegiatan fisik, yang kesemuannyaiyu melibatkan individu dalam menilai mendapatkan dan mempergunakan barang-barang dan jasa-jasa secara ekonomis.

\section{ANALISIS DAN PEMBAHASAN}

3.1 Perilaku Konsumen atas Produk Handphne Nokia di Kalangan Mahasiswa FISIP UTB Lampung

Tanggapan responden tentang apakah handphone yang anda miliki merupakan model yang disukai saat ini 


\begin{tabular}{|l|c|c|}
\hline Kategori & $\mathrm{F}$ & $\%$ \\
\hline Sangat disukai & 6 & $4,51 \%$ \\
\hline Disukai & 41 & $30,83 \%$ \\
\hline Cukup disukai & 39 & $29,32 \%$ \\
\hline Kurang disukai & 26 & $19,55 \%$ \\
\hline Tidak disukai & 21 & $15,79 \%$ \\
\hline JUMLAH & $\mathbf{1 3 3}$ & $\mathbf{1 0 0}$ \\
\hline
\end{tabular}

Dari tabel 11 diatasmenunjukan bahwa handphone yang responden miliki merupakan model yang disukai saat ini berjumlah 41 orang $(30,83 \%)$. 6 responden $(4,51 \%)$ yang menyatakan bahwa handphone yang responden miliki merupakan model yang sangat disukai saat ini dan 26 responden $(19,55)$ yang menyatakan bahwa handphone yang anda miliki merupakan model yang kurang disukai saaat ini. 21 responden $(15,79 \%)$ yang menyatakan bahwa handphone yang anda miliki merupakan model yang tidak disukai saat ini. 39 responden $(29,32 \%)$ yang menyatakan bahwa handphone yang anda miliki merupakan model yang cukup disukai saat ini.

\section{KESIMPULAN DAN SARAN}

\section{A. Kesimpulan}

Berdasarkan hasil analisis data dan pembahasan yang telah dikemukakan pada bagian terdahulu, selanjutnya dapat dikemukakan kesimpulan dalam pelaksanaan penelitian ini sebagai berikut:

> Tersendiri bagi perilaku konsumen dalam pembelian produk handphone Nokia selain masalah factor social dan budaya, seperti saran teman-teman terdekat, ataupun keluarga yang ada menjadi acuan atau informasi harga juga menjadi acuan yang penting

$>$ Dalam dimensi merek sebuah produk, factor ketahanan dan kehandalan serta faktor karakteristik produk seperti corak, penampilan, dan daya tarik produk, menjadi faktor dominan bagi konsumen mengenai kualitas produk handphone Nokia.

Berdasarkan hasil perhitungan, maka di dapat untuk rhitung adalah 0,404. Apabila dikonsultasikan dengan rtabel untuk taraf signifikan 5\% adalah 0,176 ternyata $r$ hitung lebih besar dari pada $r$ table atau:

rhitung $(0,404)>$ rtabel $(0,176)$ pada tariff signifikan 5\%, dengan demikian merek mempunyai pengaruh yang positif terhadap prilaku dikonsumen atas produk handphone Nokia di kalangan Mahasiswa FISI UTB lampung

\section{B. Saran}

1. Lebih meningkatkan kegiatan promosi produk handphone, agar konsumen lebih mengetahui lebih banyak tentang jenis produk yang diinginkan.

2. Lebih memahami keinginan konsumen dalam memilih sebuah produk melalui survey pasar.

3. Lebih meningkatkan kualitas produk dengan harga yang tetap terjangkau oleh konsumen.

\section{DAFTAR PUSTAKA}


Arikunto,Suharsini, 1997., Presedur Penelitian, Rineka Cipta, Jakarta

Arikanto, Suharsini, 2004, Presedur Penelitian, Edisi Revisi, PT.BinaAskara.

Arikanto, Suharsini, $\quad 1987$, MetedeologiResearch, UGM, Yogyakarta.

Kotler, Philip dan Garry Amstrong, (1986) Manajemen Pemasaran analisa, Perencanaan dan Pengendalian. Jilid I. Jakarta: Erlangga

Kolter, Philip dan Garry Amstrong, (1986)

Dasar-dasar pemasaran. Edisi Bahasa Indonesia. Jakarta : Prehalindo.

Kolter, Philip dan Garry Amstrong. (terj). (1990). Manajemen pemasaran Analisis Implementasi dan Pengendalian. Jakarta : Erlangga

Kolter, Philip dan Garry Amstrong. (terj.) (1992). Prinsip-prinsip Pemasaran Jilid I. Jakarta. 